\title{
Editor to quit over hoax open-access paper
}

The editor-in-chief of an open-access journal is to resign after claiming that its publisher, Bentham Science Publishing, accepted a hoax article without his knowledge.

Bambang Parmanto, an information scientist at the University of Pittsburgh, Pennsylvania, and editor-in-chief of The Open Information Science Journal, said he had not seen the computer-generated manuscript, accepted by Bentham on 3 June.

The fake paper was submitted by Philip Davis, a graduate student in communication sciences at Cornell University in Ithaca, New York, and Kent Anderson, an executive director at The New England Journal of Medicine. Davis says he wanted to test if the publisher would "accept a completely nonsensical manuscript if the authors were willing to pay". He retracted the paper after being notified that it had been accepted, and that he should pay US $\$ 800$ to Bentham's subscription department.

Mahmood Alam, director of publications at Bentham Science Publishing, told Nature that "submission of fake manuscripts is a totally unethical activity and must be condemned", adding that "a rigorous peerreview process takes place for all articles that are submitted to us for publication". For a longer version of this story, see http://tinyurl.com/Irx6m6

\section{FDA gains the power to regulate tobacco products}

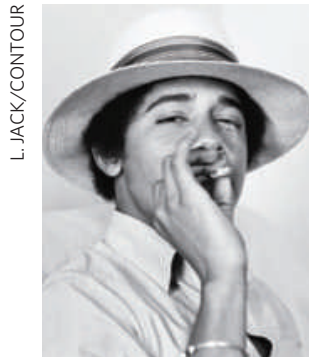

Obama in his youth.
The US Food and Drug Administration (FDA) will get the power to regulate tobacco for the first time in its 103year history under legislation passed by Congress last week. President Barack Obama, himself a sometime smoker (see picture), has promised to sign the bill into law.

Passed by substantial majorities in both the House and the Senate, the Family Smoking Prevention and Tobacco Control Act requires that new tobacco products win pre-market approval from the FDA.

The bill bars the FDA from banning nicotine, but it gives the agency standardsetting authority that could lower nicotine levels in tobacco products. It constrains advertising, requires large warning labels on packaging and levies user fees paid by the industry to help finance FDA regulation. The fees will total \$235 million in 2010.

\section{Infrared scan reveals colourful past of the Parthenon}

Conservation scientists at the British Museum in London have found the first evidence of coloured pigments on sculptures from the Acropolis in Athens. The figures formed part of the decoration on the Parthenon temple, and were taken from Greece by Lord Elgin in the early 1800s.

Ancient Greeks and Romans normally painted their sculptures, and traces of the pigments tend to survive on the objects to this day. But no hints of paint had been found on the Parthenon sculptures despite detailed studies - including an analysis in the 1830 s by English physicist Michael Faraday.

The researchers revealed the presence of a pigment known as Egyptian blue on the belt of the goddess Iris (pictured).

They used a portable detector to beam red light onto the surface and capture the infrared light emitted by the luminescent pigment particles (inset).

For a longer version of this story, see http://tinyurl.com/m24ylw
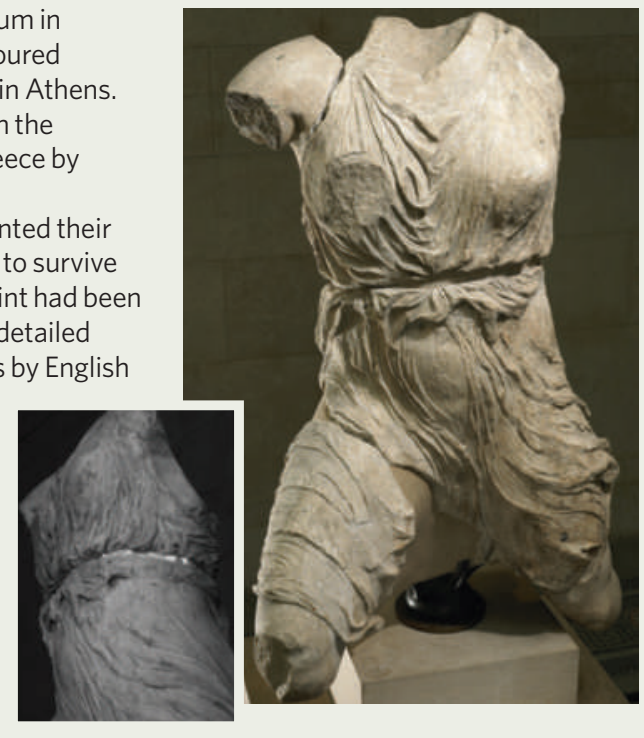

\section{Japan's lunar orbiter ends mission with crash landing}

The Japanese space agency's KAGUYA lunar orbiter ended its 21-month mission with a planned crash into the Moon on 10 June.

Formally known as SELENE

(Selenological and Engineering Explorer), the mission was launched in September 2007. The orbiter gathered detailed geological information about the Moon, mapping its gravitational field and taking high-definition video images.

As Nature went to press, NASA's Lunar Reconnaissance Orbiter was scheduled to launch on 18 June. Together with India's Chandrayaan-1 spacecraft, which launched in October 2008, it will attempt to spot water ice at the Moon's poles (see Nature 459, 758-759; 2009).

\section{Artefact raiders charged after undercover operation}

A two-year federal investigation of widespread Native American grave robbing and artefact theft in the Four Corners region of the United States culminated in charges against 24 people last week.

The arrested individuals, from Utah, Colorado and New Mexico, were arraigned in the federal court on 10 and 11 June for multiple felony indictments for trade in 256 artefacts with a total value of more than US\$335,000. Purloined items included pottery, baskets, sandals and necklaces taken from excavations on federal lands.

An undercover agent purchased the looted artefacts from, among others, a high-school teacher and an honoured archaeologicaltourism promoter. One man - James Redd, a physician from Blanding, Utah committed suicide on 11 June, authorities say, the day after he and his wife were charged with artefact theft.

\section{US revives FutureGen 'clean' coal plant}

The US Department of Energy (DOE) has announced plans to revive FutureGen, a commercial-scale coal-fired power plant in Mattoon, Illinois, that would capture carbon dioxide emissions and sequester them underground.

Under George W. Bush's administration, the DOE pulled the plug on the flagship 'clean' coal technology programme in January 2008, citing a dispute with industry partners over the US\$1.8-billion price tag (see Nature 451, 612-613; 2008).

Energy secretary Steven Chu revived FutureGen on 12 June, announcing an agreement to restart the negotiations, update the cost estimate and begin preliminary design activities. The DOE and FutureGen industry partners hope to make a final decision on whether to go ahead with the project early in 2010.

\section{Corrections}

The News Feature 'Sucking it up' (Nature 458, 1094-1097; 2009) incorrectly stated that Global Thermostat is waiting for venture-capital funding to build a prototype for the capture of $\mathrm{CO}_{2}$ from the air. It already has sufficient funding in place.

The News story 'Funding struggle for mercury monitoring' (Nature 459, 620-621; 2009) erroneously located Changbai Mountain in Taiwan. It is in northeastern China.

In the News Feature 'Nascence man' (Nature 459, 316-319; 2009), the picture of the Lost City on page 318 should have been credited to D. S. Kelley. 